\title{
HYBRID PROCEDURES IN TREATMENT OF PERIPHERAL ARTERIAL DISEASE
}

\section{HIBRIDNE PROCEDURE U LEČENJU PERIFERNE ARTERIJSKE OKLUZIVNE BOLESTI}

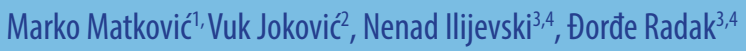

\begin{abstract}
Summary
Peripheral arterial disease is common in the developed world, affecting approximately $14 \%$ to $20 \%$ of the adult population. The determination of the best method of revascularization or treatment of symptomatic peripheral arterial disease (PAD) is based upon the balance between risk of a specific intervention and the degree and durability of the improvement that can be expected from this intervention. Hybrid revascularization combines open surgery with endovascular procedures to treat multilevel vascular disease. The use of hybrid procedures permits vascular reconstruction that is less invasive than traditional surgical repair. The optimal strategy for revascularization will continue to evolve, but surgery continues to play a significant role in managing patients with PAD.
\end{abstract}

Keywords: peripherial arterial oclusive disease, treatment of symptomatyc peripheral arterial disease, hybrid procedures

\section{Sažetak}

Periferna arterijska okluzivna bolest je česta u razvijenom svetu, njome je pogođeno otprilike 14 do 20\% odrasle populacije. Odluka o izboru najboljeg načina za revaskularizaciju i lečenje pacijenata sa simptomatskom perifernom arterijskom bolešću bazira se na balansu između rizika koji nosi specifična intervencija i stepenu i trajnosti poboljšanja koji se očekuje od primenjene procedure. Hibridne procedure kombinuju otvorenu hirurgiju sa endovaskularnim tehnikama u lečenju vaskularne bolesti na više nivoa. Upotreba hibridnih procedura dopušta rekonstrukciju krvnih sudova koje je manje invazivno od tradicionalnog hirurškog lečenja. Optimalna strategija za revaskularizaciju će nastaviti da se menja, ali hirurgija nastavlja da i dalje igra značajnu ulogu u tretmanu pacijenata sa perifernom arterijskom bolešću.

Ključne reči: periferna arterijska okluzivna bolest, tretman simptomatske periferne arterijske bolesti, hibridne procedure

\section{UvoD}

Periferna arterijska okluzivna bolest je česta u razvijenom svetu. Njome je pogođeno otprilike 14 do $20 \%$ odrasle populacije. Hronična ishemija donjih ekstremiteta uključuje dva entiteta: intermitentnu klaudikaciju, i mnogo teži oblik, kritičnu ishemiju donjih ekstremiteta. Incidenca hronične ishemije donjih ekstremiteta raste sa porastom broja starije populacije. Pacijenti kod kojih je postavljena dijagnoza periferne arterijske bolesti imaju veću verovatnoću da će biti podvrgnuti amputaciji donjih ekstremiteta, i što je još značajnije oni su pod povećanim rizikom da će oboleti ili umreti od srčanih i cerebrovaskularnih ishemijskih bolesti u odnosu na bolesnike koji ne boluju od periferne arterijske bolesti.

Odluka o izboru najboljeg načina za revaskularizaciju i lečenje pacijenata sa simptomatskom perifernom arterijskom bolešću bazira se na balansu između rizika koji nosi specifična intervencija i stepenu i trajnosti poboljšanja koji se očekuje od primenjene procedure. Definisanje lokacije i morfologije same bolesti je neophodno pre primene bilo kakve revaskularizacione procedure da bi se odredio najprikladniji metod intervencije. Uopšteno uzev, ishod same revaskularizacione procedure zavisi od proširenosti same bolesti u pogođenom arterijskom stablu (inflow, outflow i veličina i dužina obolelog segmenta), od eventualnih sistemskih bolesti (komorbidna stanja koja imaju uticaj na očekivanu dužinu života i uticaj na prohodnost samog grafta) i od vrste primenjene procedure.

Revaskularizacija kod pacijenata sa perifernom arterijskom bolešću može biti postignuta na nekoliko načina:

1. endovaskularne tehnike koje se koriste u lečenju periferne arterijske bolesti su balon dilatacija sa ili bez plasiranja stenta, plasiranje stent graftova, endovaskularno uklanjanje aterosklerotskih plakova.

2. hirurške opcije uključuju bajpas procedure bilo autogenim ili sintetskim graftovima i endarterektomije.

3. revaskularizacija ovih bolesnika može se postići i primenom kombinovanih procedura koje uključuju primenu endovaskularnih i otvoreno-hirurških metoda. 
KOMBINOVANA ENDOVASKULARNA I HIRURŠKA REVASKULARIZACIJA

Primena kombinovanih procedura u lečenju periferne arterijske bolesti datira od 70'ih godina prošlog veka sa kombinovanjem ilijačne angioplastike i femoro-femoralnog bajpasa (1). Prema trenutnim podacima hibridne procedure učestvuju sa 5 do $21 \%$ u ukupnom broju vaskularnih rekonstrukcija (2).

Hibridne procedure kombinuju otvorenu hirurgiju sa endovaskularnim tehnikama u lečenju vaskularne bolesti na više nivoa. Kod hibridnih procedura endovaskularna komponenta može se upotrebiti za rešavanje bilo inflow (3-5), outflow (5), kombinaciju inflow i outflow segmenta (6), kao i za reviziju bajpas grafta (6). Endovaskularni i otvoreni deo kombinovane procedure može biti primenjen simultano ili sekvencijalno. Hibridne procedure omogućavaju da pacijenti, za koje se smatra da su pod povišenim rizikom za tradicionalnu kompletnu hiruršku rekonstrukciju, budu podvrgnuti trajnoj revaskularizaciji manje ekstenzivnom procedurom, koja kraće traje i koja smanjuje rizik od perioperativnih komplikacija (7-9). Za pacijente sa kritičnom ishemijom donjeg ekstremiteta procenat spasavanje uda nakon primene hibridne revaskularizacije kreće se od 80 do $100 \%$ $(3,10,11)$.

\section{INDIKACIJE ZA KOMBINOVANE PROCEDURE}

\section{Hronična ishemija ekstremiteta}

Periferna arterijska okluzivna bolest donjih ekstremiteta se klinički prezentuje kao intermitentna klaudikacija ili kritična ishemija. Kritična ishemija ekstremiteta je manifestacija periferne arterijske okluzivne bolesti, koja se ispoljava kod bolesnika u vidu ishemijskog bola $\mathrm{u}$ miru i pojave ulkusa ili gangrene na stopalu ili bilo kom delu donjeg ekstremiteta. Kritična ishemija nastaje najčešće kao posledica arterijske okluzivne bolesti koja zahvata više nivoa arterijskog stabla (12). Oslobađanje pacijenata od bola i postizanje zarastanja ulkusa ili lečenje gangrane često zahteva potpunu revaskularizaciju svih pogđenih nivoa arterijskog stabla bilo otvorenom hirurgijom, endovaskularnim procedurama ili njihovom kombinacijom, što u krajnjem ishodu treba da dovede do obnove cirkulacije u pedalnim krvnim sudovima.

Revaskularizacija samo jednog segmenta arterijskog stabla je često nedovoljna i retko dovodi do zarastanja ishemijskih promena na donjim ekstremitetima (13). Prednost endovaskularnim procedurama treba dati kod starijih visokorizičnih pacijenata čija je očekivana dužina života manja od dve godina (14). Osim kod pacijenata koji mogu imati korist od obe vrste intervencija, bilo endovaskularnih, bilo otvoreno-hirurških u tretmanu kritične ishemije, postoji značajna grupa pacijenata kod kojih bi samostalna primena bilo endovaskularnih, bilo otvoreno-hirurških metoda bila tehnički neizvodljiva ili njihovom primenom ne bi došlo do očekivanih rezultata. U praksi se često javljaju situacije kada je teško izvesti endovaskularnu proceduru zbog kalcifikacija i stenoze dovodnih (inflow) arterija (obično AFC i/ili ilijačne arterije), čak i pri primeni cross over strategije. Više autora su objavili da je incidenca restenoza nakon ilijačne angioplastike u kombinaciji sa infraingvinalnom rekonstukcijom niska kod odabranih grupa bolesnika $(3,5)$.

Najčešće kombinovane procedure u tretmanu hronične ishemije jesu ilijačna angioplastika sa infraingvinalnom rekonstrukcijom (endarterektomija zajedničke femoralne arterije (AFC) ili infraingvinalni bypass), infraingvinalna rekonstrukcija (natkoleni bypass) sa infrapoplitealnom angioplastikom ili kombinacija angioplastike površne butne arterije (AFS) sa popliteo-kruralnim/ pedalnim bypass-om. Lečenje hronične ishemije donjih ekstremiteta kombinovanim procedurama povezano je sa visokim procentom tehničkog uspeha, dobrom primarnom i sekundarnom prohodnošću arterije i grafta, visokim procentom spasavanja ekstremiteta i isplativošću procedure koja kombinuje prednosti obe tehnike. Najveća studija koja podupire ove tvrdnje objavljena je 1997. god od strane Madera, i ona je uključivala primenu balon angioplastike na 336 vaskularnih segmenata kao deo 239 procedura revaskularizacije donjih udova kod 200 pacijenata (15).

\section{Akutna ishemija ekstremiteta}

Akutna ishemija ekstremiteta je akutno nastalo stanje koje neposredno ugrožava ekstremitet, a može biti uzrokovano embolizacijom, arterijskom trombozom, ili akutnom okluzijom grafta. Rizik za gubitak ekstremiteta kreće se od 5 do $30 \%$, a mortalitet od 11 do $18 \%$ (16). Osnovne terapijske opcije u adekvatnim slučajevima mogu biti: endovaskularne procedure (tromboliza/aspiracija), hirurška revaskularizacija (tromboembolektomija), ili konzervativni tretman (heparinizacija, vazodilatatori).

Hibridne procedure mogu biti opcija kod pacijenata kod kojih kontrolna angiografija nakon hirurške tromboembolektomije otkrije lezije inflow ili outflow segmenta. Angiografija može otkriti stenozu, okluziju, disekciju, aneurizmu inflow/outflow segmenta, ili prisustvo rezidualne tromboze pa ova stanja mogu biti tretirana endovaskularnom procedurom, uključujući balon angioplastiku, plasiranje stenta ili tromboaspiraciju (tip I hibridni postupak) (17). U slučajevima kada je hirurška tromboembolektomija nedovoljna i kada tromb i dalje perzistira, kombinacija hirurških procedura sa trombolizom pre ili posle hirurgije (tip II hibridni postupak), ili kombinacija endovaskularnih tehnika sa lokalnom trombolizom (tip III hibridni postupak) može pružiti zadovoljavajuće rezultate (17). Intraoperativna fibrinolitička terapija je nedavno preporučena kao važna alternativa mehaničkoj tromboembolektomiji u uklanjanju rezidulnih tromba. 


\section{Okluzija vaskularnog grafta}

Okluzija grafta u okviru mesec dana nakon vaskularne rekonstrukcije (rana okluzija) je najčešće posledica tehničke greške ili pogrešne (preambiciozne) procene o mogućnosti revaskularizacije, i rana revizija je neophodna. Okluzija koja je nastala u periodu između jednog meseca i 18 meseci od vaskularne operacije je obično uzrokovana neointimalnom hiperplazijom koja se javlja u distalnoj anastomozi. Zatvaranje grafta nakon 18 meseci od vaskularne rekonstrukcije (kasna okluzija) je uglavnom posledica ateroskleroze koja zahvata dovodne i odvodne delove arterijskog stabla (18).

Rekanalizacija okludiranog grafta može se postići hirurškom trombektomijom sa ili bez revidiranja anastomoze, perkutanom trombolizom sa ili bez angioplastike, ili zamenom starog novim bajpasom. Hirurška trombektomija može brzo očistiti graft ali bez rešavanja osnovnog uzroka koji je doveo do okluzije može imati samo privremeni efekat $(19,20)$. Hirurška trombektomija protetskih graftova sa intraoperativnom angioplastikom je alternativni metod hirurškim i endovaskularnim metodama koje se primenjuju samostalno. Kod primene ove metode koja je minimalno invazivna, i koja se može sprovesti u lokalnoj anesteziji rizik, od primene trombolitičke terapije se eliminiše, postiže se brzo uklanjanje ugruška iz proteze, tretira se moguća stenoza angioplastikom i mogu se korigovati dovodni i odvodni segmenti vaskularnog stabla, ako je to potrebno (21).

Kao što je napred navedeno endovaskularni i otvoreni deo kombinovane procedure može biti sproveden simultano ili sekvencijalno. Pre pojave modernih endovaskularnih operacionih sala, kombinovane procedure su često sprovođene sekvencijalno zato što su snimanja $\mathrm{u}$ namenskim angiografskim salama superiorna u odnosu na snimanja u klasičnim operacionim salama, a okruženje $u$ angiografskim salama je bilo neadekvatno za otvorene postupke. Sada savremene bolnice imaju namenske sale za kombinovane procedure. Kombinovane procedure mogu biti sprovedene u tri različita tipa operacionih sala i okruženja. Prvi tip sale je interventno radiološka sala koja je u potpunosti opremljena za endovaskularne procedure, uključujući adekvatne alate za obradu slike i široku paletu endovaskularnih instrumenata i materijala. Međutim, ovaj tip sale nije idealna za otvorenu hirurgiju. Druga opcija uključuje klasičnu operacionu salu koja je idealna za otvorenu revaskularizaciju, ali je obično opremljena samo mobilnim rendgen $\mathrm{C}$ lukom. Ovi nedostaci mogu biti umanjeni primenom savremenih tehnoloških rešenja. Moderni C luk već poseduje sposobnost digitalne subtrakcione angiografije sa visokom rezolucijom što omogućava mapiranje puteva, backup podataka itd. Sterilnost, osvetljenje i rukovanje operacionim stolom su prednosti operacione sale. Iako kvalitet slike nikada neće biti isti kao u klasičnim angiosalama, ipak u većini slučajeva je bolje da se hibridna procedura obavi u ovako opremljenoj operacionoj sali.
Treće, i idealno rešenje je posebna hibridna operaciona sala koja kombinuje prednosti predhodne dve, ali po znatno višoj ceni.

Sam postupak hibridne procedure skoro uvek zahteva pristup jednoj ili obema femoralnim bifrukacijama. Femoralna bifrukacija je takođe najčešće mesto za proksimalnu/distalnu anastomozu, kao i mesto gde se obično započinje tromboembolektomija. Izuzetak predstavlja angioplastika površne butne arterije (AFS) i poplitealne arterije (AP), koja se koristi u kombinaciji sa popliteokruralnim bajpasom. Pristupna tačka za retrogradnu angioplastiku je poplitealna arterija, gde će proksimalna anastomoza biti postavljena kasnije (22). Većina vaskularnih centara prvo sprovodi angioplastiku, a nakon toga mesto punkcije arterije se koristi za kreiranje anastomoze ili endarterektomiju $(23,24,25)$. Suprotan pristup se takođe primenjuje kada procedura započinje otvorenom hirurgijom (26). Vodič se uvodi na mestu proksimalne anastomoze grafta, a procedura se kompletira angioplastikom (27). Prednost ovakvog pristupa je što dozvoljava mogućnost provere prohodnosti rekonstrukcije bez dodatne punkcije. Nedostatak predstavlja to što tokom angioplastike dolazi do privremenog prekida cirkulacije pa postoji mogućnost tromboze grafta. To se eliminiše adekvatnom heparinizacijom.

Prednosti simultano sprovedenih kombinovanih procedura su sledeće: nema odlaganja u kompletnoj revaskularizaciji ishemičnog ekstremiteta, otvorena hirurgija može odmah popraviti slab endovaskularni rezultat i obrnuto, postpunkcione komplikacije koje nastaju prilikom angioplastike su eliminisane, potencijalne infektivne komplikacije koje mogu nastati prilikom primene zasebnih procedura su svedene na minimum, usklađivanje terapije između dve procedure nije obavezno, dužina hospitalizacije je kraća, zbog moguće rutinske primene angiografije na kraju intervencije hirurzi imaju bolju kontrolu i verifikaciju postignutih rezultata.

\section{ZaKLJUČAK}

Hirurška revaskularizacija predstavlja osnovu terapije za odabrane pacijente sa teškom ishemijom ekstremiteta. Napredak u proceni medicinskih rizika, preoperativna priprema i postoperativna terapija su doprineli napretku u hirurškom lečenju. Upotreba hibridnih procedura dopušta rekonstrukciju krvnih sudova koje je manje invazivno od tradicionalnog hirurškog lečenja kao i onih koji nikada nisu dostupni hirurškom lečenju. Optimalna strategija za revaskularizaciju će nastaviti da se menja, ali hirurgija nastavlja da i dalje igra značajnu ulogu u tretmanu pacijenata sa perifernom arterijskom bolešću. 


\section{Literatura}

1. Porter JM, Eidemiller LR, Dotter CT et al: Combined arterial dilatation and femorofemoral bypass for limb salvage. Surg Gynecol obstet 1973;137:409-412

2. Ebaugh JL, Gagnon D, Owens CD et al: Comparison of costs of staged versus simultaneous lower extremity arterial hybrid procedures. Am J Surg 2008;196:634-640

3. Miyahara T, Miyata T, Shigematsu H, Shigematsu K, Okamoto H, Nakazawa T, Nagawa H. Long-term results of combined iliac endovascular intervention and infrainguinal surgical revascularization for treatment of multilevel arterial occlusive disease. Int Angiol. 2005;24: 340-348.

4. Schneider PA, Caps MT, Ogawa DY, Hayman ES. Intraoperative superficial femoral artery balloon angioplasty and popliteal to distal bypass graft: an option for combined open and endovascular treatment of diabetic gangrene. J Vasc Surg. 2001;33:955-962.

5. Cotroneo AR, Iezzi R, Marano G, Fonio P, Nessi F, Gandini G. Hybrid therapy in patients with complex peripheral multifocal steno-obstructive vascular disease: two-year results. Cardiovasc Intervent Radiol. 2007;30: 355-361.

6. Dougherty MJ, Young LP, Calligaro KD. One hundred twenty-five concomitant endovascular and open procedures for lower extremity arterial disease. J Vasc Surg. 2003;37:316 -322.

7. Dosluoglu HH, O’Brien-Irr MS, Lukan J, Harris LM, Dryjski ML, Cherr GS. Does preferential use of endovascular interventions by vascular surgeons improve limb salvage, control of symptoms, and survival of patients with critical limb ischemia? Am J Surg. 2006;192:572-576.

8. Melliere D, Cron J, Allaire E, Desgranges P, Becquemin JP. Indications and benefits of simultaneous endoluminal balloon angioplasty and open surgery during elective lower limb revascularization. Cardiovasc Surg. 1999;7:242-246.

9. Clement C, Costa-Foru B, Vernon P, Nicaise H. Transluminal angioplasty performed by the surgeon in lower limb arterial occlusive disease: one hundred fifty cases. Ann Vasc Surg. 1990;4:519 -527.

10. Dosluoglu HH, Lall P, Cherr GS, Harris LM, Dryjski ML. Role of simple and complex hybrid revascularization procedures for symptomatic lower extremity occlusive disease. J Vasc Surg. 2010;51:1425-1435.e1.

11. Lantis J, Iensen M, Benvenisty A, Mendes D, Gendics C, Todd G. Outcomes of combined superficial femoral endovascular revascularization and popliteal to distal bypass for patients with tissue loss. Ann Vasc Surg. 2008;22:366 -371.

12. Norgren L, Hiatt WR, Dormandy JA et al: Inter-Society Consensus for the Management of Peripheral Arterial Disease (TASC II). Eur J Vasc Endovasc Surg 2007;33 Suppl 1:S1-75.
13. Siskin G, Darling RC 3rd, Stainken B et al: Combined use of iliac artery angioplasty and infrainguinal revascularization for treatment of multilevel atherosclerotic disease. Ann Vasc Surg 1999;13:45-51.

14. Arvela E, Venermo M, Soderstrom M et al: Infrainguinal percutaneous transluminal angioplasty or bypass surgery in patients aged 80 years and older with critical leg ischaemia. Br J Surg 2011;98:518-526

15. Madera FA, Orecchia PM, Razzino RA et al: Balloon angioplasty by vascular surgeons. Am J Surg 1997;174:152-156.

16. Tawes RL Jr., Harris EJ, Brown WH et al: Arterial thromboembolism. A 20-year perspective. Arch Surg 1985;120:595-599.

17. de Donato G, Setacci F, Sirignano P et al: Hybrid procedures for acute limb ischemia. J Cardiovasc Surg 2010;51:845-853.

18. Belkin M: Secondary bypass after infrainguinal bypass graft failure. Semin Vasc Surg 2009;22:234-239.

19. Weaver FA, Comerota AJ, Youngblood M et al: Surgical revascularization versus thrombolysis for nonembolic lower extremity native artery occlusions: results of a prospective randomized trial. The STILE Investigators. Surgery versus Thrombolysis for Ischemia of the lower Extremity. J Vasc Surg 1996; 24:513-521; discussion 521-513.

20. Bull PG, Guttierez E, Mendel H et al: Thrombolysis combined with angioplasty for failed femorodistal arterial grafts. Acta Chir Belg 1993;93:276-283.

21. Costanza MJ, Neschis DG, Queral LA et al: Surgical thrombectomy and transluminal balloon angioplasty for failed aboveknee femoropopliteal polytetrafluoroethylene bypass grafts. Ann Vasc Surg 2004;18:186-192.

22. Schneider PA: Balloon angioplasty and stent placement during operative vascular reconstruction for lower extremity ischemia. Ann Vasc Surg 1996;10:589-598.

23. Schrijver AM, Moll FL, De Vries JP: Hybrid procedures for peripheral obstructive disease. J Cardiovasc Surg 2010;51:833-843.

24. Schneider PA: Iliac angioplasty and stenting in association with infrainguinal bypasses: timing and techniques. Semin Vasc Surg 2003;16:291-299.

25. Slovut DP, Sullivan TM: Combined endovascular and open revascularization. Ann Vasc Surg 2009;23:414-424.

26. Aho P, Venermo M: Hybrid procedures as a novel technique in the treatment of critical limb ischemia. Scand J Surg 2012; 101:107-113.

27. Balaz P, Rokosny S, Koznar B et al: Combined infrainguinal reconstruction and infrapopliteal intraluminal angioplasty for limb salvage in critical limb ischemia. Interact Cardiovasc Thorac Surg 2009;9:191194. 